Ivana Prpić

Dječji vrtić Matije Gupca

Zagreb, Hrvatska

i.prpic79@gmail.com
UDK: 371.3::796-053.4

Originalni naučni rad

Primljen: 30. 10. 2021.

Korigovan: 28. 11.2021.

Prihvaćen: 12. 12. 2021.

DOI: https://doi.org/10.53406/kd.v9i2.26

\title{
STAVOVI ODGOJITELJA O KINEZIOLOŠKIM AKTIVNOSTIMA NA OTVORENOM ZA DJECU RANE I PREDŠKOLSKE DOBI
}

Sažetak: Kineziološke aktivnosti u ranom i predškolskom odgoju i obrazovanju predstavljaju različite vrste tjelesnog vježbanja. Svrha im je osigurati motoričku pismenost djece kako bi se omogućio cjelovit i planski utjecaj na njihovu motoriku $i$ optimalan razvoj antropoloških obilježja. Za većinu djece rane i predškolske dobi odgojitelji su prve osobe koje organiziraju i provode kineziološke aktivnosti i rukovoditelji su u tjelesnom i zdravstvenom odgojno-obrazovnom području u ustanovi ranog $i$ predškolskog odgoja. Istraživanja su pokazala da tjelesne aktivnosti na otvorenom značajno doprinose pozitivnom razvoju antropoloških obilježja djece, stoga kada god mikroklimatski uvjeti dozvoljavaju, odgojitelji bi se trebali odlučiti na vanjski prostor za realizaciju kinezioloških aktivnosti. U radu se ispituju stavovi $i$ gledišta odgojitelja zaposlenih u dječjim vrtićima, s ciljem postizanja boljeg razumijevanja čimbenika koji podržavaju ili ograničavaju kineziološke aktivnosti na otvorenom djece rane i predškolske dobi. Rezultati istraživanja pokazali su da vlastita uvjerenja odgojitelja i uvjeti u vrtiću imaju najveći utjecaj na donošenje odluke o vježbanju s djecom na otvorenom. Većina ispitanih odgojitelja uglavnom se izrazito slaže s važnošću provođenja kineziološke kulture na otvorenom, ipak rezultati pokazuju nižu procjenu provođenja.

Ključne riječi: rani i predškolski odgoj, kineziološke aktivnosti na otvorenom, stavovi odgojitelja, tjelesna i zdravstvena kultura. 


\section{Uvod}

$\mathrm{U}$ današnje vrijeme raste zabrinutost zbog niske razine tjelesne aktivnosti i povezanih zdravstvenih problema u djece. Sjedilački način života u modernim društvima globalni je problem (WHO, 2016) i započinje rano u djetinjstvu. Kretanje, kao biološka čovjekova potreba, uvelike izostaje u suvremenom načinu života (Sindik, 2009), kako kod djece tako i kod odraslih. Prema Petrić (2019), jedan od razloga može biti što djeca danas sve manje vremena provode u igri, a još manje u prirodi samostalno istražujući svijet oko sebe. Drugi negativan trend odnosi se na značajan pad funkcionalnih sposobnosti djece i mladih u Europi, gdje se predviđa da će svaka sljedeća generacija djece biti lošijih funkcionalnih sposobnosti od one prethodne (Gašparović, Petrić, Stemberger, Rakovac i Blažević, 2017).

Poznato je da tjelesne aktivnosti u prirodi značajno doprinose pozitivnom razvoju i napretku antropoloških obilježja učenika, posebno aerobnih sposobnosti te značajno utječu na njihovu ukupnu dnevnu tjelesnu aktivnost (Novak, Petrić, Jurakić, \& Rakovac, 2014). Upravo tjelesne aktivnosti u prirodi u kojima dominira aerobna komponenta mogu značajno utjecati na smanjenje prekomjerne tjelesne mase i pretilosti (Petrić, Cetinić i Novak, 2010). Kontinuirano tjelesno vježbanje od najranije dobi može uravnotežiti rast i razvoj djeteta. Samim time organiziranje tjelesnog vježbanja na otvorenome, neovisno o vremenskim uvjetima imati će utjecaj na pozitivni razvoj funkcionalnih sposobnosti djece (Petrić, 2019). Predškolsko dijete treba zadovoljiti osnovnu ljudsku potrebu za zdravim mentalnim i tjelesnim rastom i razvojem, uključujući kretanje kao jednu od najvažnijih potreba (Prskalo, Horvat i Hraski, 2014). U zadovoljavanju te potrebe kod djece rane i predškolske dobi najvažnija je uloga roditelja i odgojitelja (Prskalo, Findak i Neljak, 2007). Stoga je važno u dječjem vrtiću primjereno zadovoljavati sve dječje potrebe, pa tako i potrebu za kretanjem, koja je u toj dobi jedna od najvažnijih.

Ovim radom željelo se ispitati stavove i gledišta odgojitelja zaposlenih u dječjim vrtićima s ciljem postizanja boljeg razumijevanja čimbenika koji podržavaju ili ograničavaju različite kineziološke aktivnosti na otvorenom djece rane i predškolske dobi.

\section{Vrste kinezioloških aktivnosti za djecu rane i predškolske dobi}

Kineziološke aktivnosti u ranom i predškolskom odgoju i obrazovanju predstavljaju različite vrste tjelesnog vježbanja za djecu rane i predškolske dobi koje proizlaze iz znanstvenih i stručnih spoznaja kineziološke metodike. Svrha im je osigurati motoričku pismenost djece kako bi se omogućio cjelovit i planski utjecaj na njihovu motoriku i optimalan razvoj antropoloških obilježja (Petrić, 2019). Prema Petrić (2019), u ranom i predškolskom odgoju i obrazovanju možemo razlikovati slijedeće vrste kinezioloških aktivnosti: tjelesni odgoj, poticajno tjelesno vježbanje, jutarnje tjelesno vježbanje, tjelesno aktivne pauze, tjelesno vježbanje $s$ roditeljima, šetnja, izlet, zimovanje, ljetovanje i sportski trening. Određeni oblici u sklopu kojih se provodi tjelesno vježbanje kao što su ljetovanje, zimovanje i sportski trening izvode se samo ako postoje odgovarajući uvjeti za isto zbog njihove organizacijski zahtjevnije pripreme i provedbe. 
Temelj tjelesnog vježbanja u ustanovama ranog i predškolskog odgoja jest aktivnost tjelesnog odgoja pomoću koje dijete izgrađuje temelje opće kineziološke kulture, ali koje je ujedno i priprema djeteta za složenije tjelesno vježbanje (Petrić, 2016).

Poticajno tjelesno vježbanje odgojitelji indirektno potiču različitim materijalima koje postavljaju u prostoru. Dijete tako samostalno i prirodno započinje izvoditi motoričke sadržaje, koje za svrhu ima djetetovo zadovoljavanje osnovne (biotičke) potrebe za kretanjem.

Jutarnje tjelesno vježbanje stvoriti će pozitivno ozračje u skupini i doprinijeti lakšem uključivanju djece u aktivnosti predviđene u određenom danu.

Tjelesno aktivne pauze omogućuju aktivni odmor djetetu tijekom odgojnoobrazovnog procesa i sprječavaju daljnji rast umora.

Tjelesno vježbanje s roditeljima u ustanovi ranog i predškolskog odgoja u kontekstu kinezioloških aktivnosti prije svega za svrhu ima edukaciju roditelja o načinima provođenja kvalitetnog slobodnog vremena u pokretu s vlastitom djecom.

Šetnje omogućuju djeci organizirani boravak i kretanje na svježem zraku u trajanju od minimalno 15 min ili $500 \mathrm{~m}$. Izletom se integriraju gotovo sva područja u odgojno-obrazovnom sustavu. Mogu biti poludnevni, cjelodnevni ili višednevni. Zimovanje i ljetovanje organizirani su višednevni boravci u zimskim odnosno ljetnim uvjetima na otvorenome (Findak, 1995). Organizacijski su vrlo složeni te zahtijevaju kvalitetnu pripremu od odgojitelja.

Sportski trening u ranom i predškolskom odgoju u ustanovi ranog i predškolskog odgoja odvija se integrirano u sportski program unutar redovitog programa ustanove ili kao sportski trening u specijaliziranim sportskim programima nakon redovitog programa ustanove i za svrhu ima usmjeravanje djece prema određenom sportu od najranije dobi.

Okruženje za realizaciju kinezioloških aktivnosti u ustanovi ranog i predškolskog odgoja i obrazovanja podrazumijeva zatvorene i otvorene prostore, kao i opremu. Zatvoreni prostori su sportske dvorane, prilagođeni prostori za tjelesno vježbanje ili skupina dnevnog boravka djece. Otvoreni prostori kao što su vanjska igrališta i otvoreni tereni u sklopu ustanove, razne travnate površine, trim staze ili specifična mjesta kao što su šume, javne plaže i sl. mogu se primjenjivati za realizaciju kinezioloških aktivnosti (Petrić, 2019). Navedeni prostori potiču aktivnosti u prirodi koje mogu biti temelj za stvaranje navike redovitog i cjeloživotnog tjelesnog vježbanja (Alić, Petrić i Badrić, 2016).

\section{Metodologija}

Cilj istraživanja je ispitati stavove i gledišta odgojitelja zaposlenih u dječjim vrtićima s ciljem postizanja boljeg razumijevanja čimbenika koji podržavaju ili ograničavaju kineziološke aktivnosti na otvorenom djece rane i predškolske dobi.

U istraživanju je korišten onlajn anketni upitnik, a u dijelu anketnog upitnika koji se odnosi na prepreke za provođenje kinezioloških aktivnosti na otvorenome anketni upitnik djelomično je preuzet od Sandseter, Cordovil, Hagen i Lopes (2019). U anketnom upitniku korištena je Likertova petostupanjska skala. Devet čestica procjenjuje korisnost kinezioloških aktivnosti na otvorenom, a sedam čestica provedbu različitih kinezioloških aktivnosti na otvorenome u odgojno-obrazov- 
nom radu odgojitelja ranog i predškolskog odgoja i obrazovanja. Istraživanje je provedeno na internetu sa 128 odgojitelja zagrebačkih vrtića u dobi od 21 do 56 i više godina. Najveći dio ispitanika $(52,3 \%)$ je u dobi od 36 do 45 godina. U dobi od 26 do 35 je 20,3\% odgojitelja, a 18,8\% odgojitelja je u dobi od 46 do 55 godina. Odgojitelja u dobi od 56 i više godina je 7\% i najmanje je odgojitelja u dobi od 21 do 25 godina (1,6\%). Prema spolu 4 odgojitelja je muškog spola, a 124 odgojitelja je ženskog spola. U odnosu na godine radnog iskustva $25,8 \%$ odgojitelja ima 20 i više, $25 \%$ ima od 10 do 15 godina radnog iskustva, od 15 do 20 njih $21,1 \%, 19,5 \%$ ima od 5 do 10 , te od 1 do 5 godina radnog iskustva ima 8,6\% odgojitelja.

\section{Rezultati}

U nastavku su prikazani rezultati istraživanja koji su usmjereni na perspektivu odgojitelja predškolske djece vezanu uz provođenje kinezioloških aktivnosti na otvorenom.

Na pitanje „Koje su po Vašem mišljenju prepreke za provođenje kinezioloških aktivnosti na otvorenom?” (Dijagram 1.) odgojitelji su odgovorili na sljedeći način: prepreku „nedostatak opreme” označili su u najvećem omjeru (46,9\%), zatim prepreku „,vremenski uvjeti” (26,6\%), slijedi „nedostatak prostora” (24,2\%), „nedostatak vremena” $(8,6 \%)$, „strah od ozljede” $(8,6 \%)$ te u najmanjoj mjeri „djeca se mogu zaprljati” (2,3\%). Odgovor "ništa od navedenog” označen je u omjeru od $34,4 \%$.

Koje su po Vašem mišljenju prepreke za provođenje kinezioloških aktivnosti na otvorenom? (moguće više odgovora)

128 responses

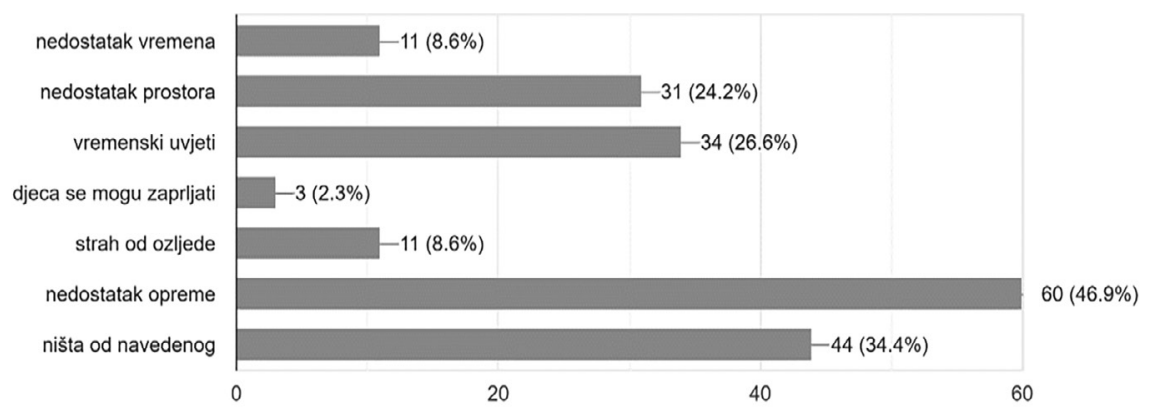

Dijagram 1. Prepreke za provođenje kinezioloških aktivnosti na otvorenom

Na pitanje „Po Vašem mišljenju, što utječe na odluku o provođenju kinezioloških aktivnosti na otvorenome?" (Dijagram 2.), gdje je postojala mogućnost označavanja više odgovora, u najvećem omjeru $(75,8 \%)$ odgojitelji su označili „vlastita uvjerenja”, zatim "materijalni uvjeti u ustanovi” (44,5\%), „kurikulum ustanove” $(21,9 \%)$ i u najmanjoj mjeri "očekivanja od roditelja" (12,5\%). Ovi rezultati po- 
tvrđuju činjenicu da vlastita uvjerenja odgojitelja, a zatim i materijalni uvjeti u ustanovi (Kalpogianni, 2019) u najvećoj mjeri utječu na pružanje kinezioloških aktivnosti na otvorenome.

Po Vašem mišljenju, što utječe na odluku o provođenju kinezioloških aktivnosti na otvorenom? (moguće više odgovora)

128 responses

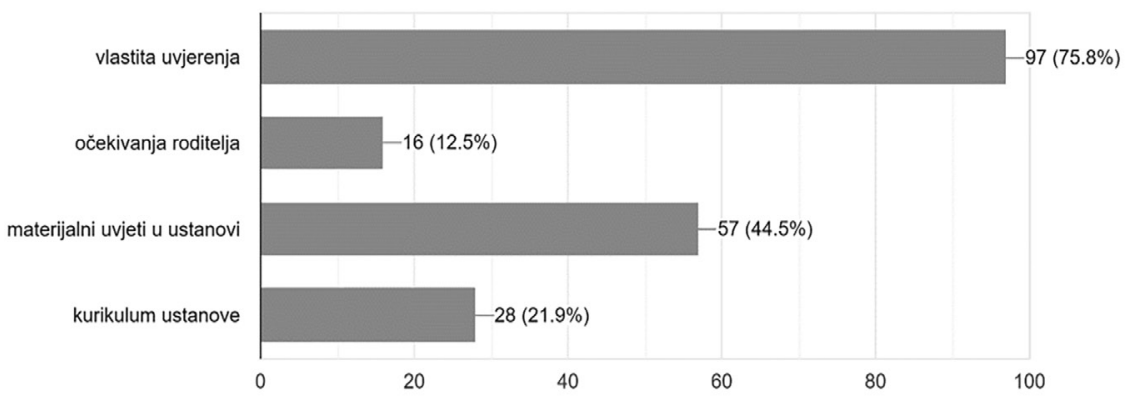

Dijagram 2. Utjecaj na odluku odgojitelja o provođenju kinezioloških aktivnosti na otvorenom

Na pitanje „Koliko često s djecom provodite sat tjelesnog odgoja (uvodni, pripremni, glavni A, glavni B i završni dio) na otvorenom?” (Dijagram 3.) 128 odgojitelja odgovorilo je na sljedeći način: najviše ispitanika $(42,2 \%)$ sat tjelesnog odgoja ne provodi na taj način na otvorenome; sat tjelesnog odgoja uopće ne provodi na otvorenom $21,9 \%$ odgojitelja; jednom tjedno ih provodi $14,8 \%$; dva puta tjedno $10,9 \%$; jednom mjesečno $5,5 \%$ i jednom u dva tjedna ih provodi $4,7 \%$.

Sat tjelesnog odgoja trebao bi biti temelj tjelesnog odgoja u ustanovama ranog odgoja koji sustavno i planski utječe na cjelokupni organizam djece, te je prema Petrić (2019) potrebno stalno mijenjati vježbovne prostore (zatvoreni i otvoreni prirodni ambijent), jer se na taj način osigurava višestruki zdravstveni doprinos i utjecaj na antropološka obilježja djece.

Koliko često s djecom provodite sat tjelesnog odgoja ( uvodni, pripremni, glavni A, glavni B i završni dio) na OTVORENOM?

128 responses
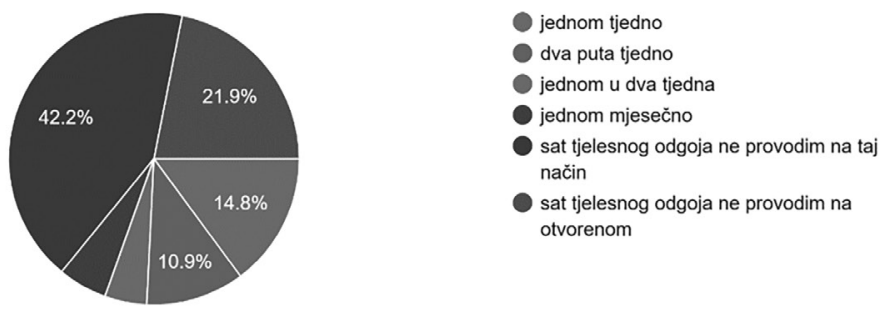

Dijagram 3. Sat tjelesnog odgoja na otvorenom 
Rezultati stavova 128 odgojitelja prema korisnosti provođenja kinezioloških aktivnosti na otvorenome pokazali su sljedeće rezultate. Sa tvrdnjom „Smatram da djeca trebaju provoditi više vremena na otvorenom" 95,3\% ispitanika izrazito se slaže. Sa tvrdnjom „Kad god vremenski uvjeti dozvoljavaju realizaciju kinezioloških aktivnosti, treba se odlučiti za vanjski prostor" većina odgojitelja $(81,3 \%)$ izrazito se slaže ili slaže $(15,6 \%)$. Samo su pojedinci stava niti se slažem, niti se ne slažem $(1,6 \%)$, ne slažem se $(0,8 \%)$ i izrazito se ne slažem $(0,8 \%)$. Većina odgojitelja izrazito se slaže $(68 \%)$ ili slaže $(23,4 \%)$ sa tvrdnjom „Organizacija kinezioloških aktivnosti može se realizirati na specifičnim mjestima kao što su šuma, voda, snijeg, led i sl."

Na tvrdnju „Rado provodim kineziološke aktivnosti s djecom na otvorenom” 74 odgojitelja $(57,8 \%)$ je odgovorilo da se izrazito slaže, $32(25 \%)$ da se slaže, 13 $(10,2 \%)$ niti se slažem niti ne slažem, $6(4,7 \%)$ se ne slaže i $3(2,3 \%)$ da se izrazito ne slaže sa ovom tvrdnjom.

S tvrdnjom „Kada god je moguće, organizacija jutarnjeg tjelesnog vježbanja treba se provoditi na otvorenim površinama" izrazito se slaže 85 ispitanih odgojitelja (66,4\%), slaže se 32 odgojitelja (25\%), a njih 11 niti se slaže, niti ne slaže $(8,6 \%)$. Izrazito je pozitivno što nitko od ispitanika nije odgovorio ne slažem se i izrazito se ne slažem. Gotovo svi autori pridaju posebnu važnost jutarnjem tjelesnom vježbanju i njegovim efektima koji se osim utjecaja na funkcionalne sposobnosti posebno odnose na vedro raspoloženje, što konsolidira dječju skupinu i čini uspješniju bilo koju aktivnost kojoj prethodi (Kinkela i Marić, 2013). Ivanković (1988) ističe da bez obzira na to što je vrijeme tog organizacijskog oblika rada relativno kratko, njegovi efekti su nezamjenjivi, a posebno ako se ista aktivnost odvija na otvorenom.

Na tvrdnju „Redovito provodim pokretne igre na zraku” većina je odgojitelja odgovorila da se izrazito slaže $(61,7 \%)$ ili slaže $(28,1 \%)$ sa ovom tvrdnjom, 11 ispitanika $(8,6 \%)$ je odgovorilo niti se slažem, niti se ne slažem, ne slažem se 1 ispitanik $(0,8 \%)$ i 1 ispitanik $(0,8 \%)$ izrazito se ne slažem. S tvrdnjom „Djecu vodim u šetnju van vrtića" izrazito se slaže 60 ispitanika (46,9\%), slaže se njih $19(14,8 \%), 15$ odgojitelja (11,7\%) niti se slaže, niti se ne slaže, njih $9(7 \%)$ se ne slaže i čak 25 ispitanih odgojitelja (19,5\%) se izrazito ne slaže. Rezultati stavova na tvrdnju „Djeci redovito osmišljavam poticajno tjelesno vježbanje na otvorenome” pokazali su da se većina ispitanika izrazito slaže $(34,4 \%)$ ili slaže $(35,9 \%)$, njih 30 $(23,4 \%)$ niti se slaže, niti se ne slaže, 6 ispitanika $(4,7 \%)$ se ne slaže i $2(1,6 \%)$ se izrazito ne slaže.

Stavovi na tvrdnju „Povremeno organiziram tjelesno vježbanje s roditeljima i djecom (zajednička druženja) na otvorenom" u većini su negativni te se ispitanici izrazito ne slažu sa tvrdnjom (25\%) ili ne slažu (24,2\%), 28 odgojitelja $(21,9 \%)$ odgovorilo je niti se slažem, niti se ne slažem, njih $16(12,5 \%)$ se slaže i $21(16,4 \%)$ se izrazito slaže sa ovom tvrdnjom. Važno je naglasiti da je svrha tjelesnog vježbanja $s$ roditeljima u kontekstu kineziološke aktivnosti prije svega edukacija roditelja o načinima provođenja kvalitetnog slobodnog vremena u pokretu s vlastitom djecom i dobrobitima kojima doprinosi tjelesna aktivnost (Petrić, 2019). Razni su načini kako se organizirano tjelesno vježbanje može provoditi u ustanovi ranog odgoja. Neke od njih su završna druženja kroz pokret, kineziološke igre, uz po- 
moć suvremene tehnologije i slično, a na odgojitelju je da na temelju svoje kreativnosti razvija takav oblik suradnje s roditeljima.

\section{Diskusija}

Ispitivanje stavova odgojitelja može poslužiti kao značajan pokazatelj u kojoj mjeri se provode različite kineziološke aktivnosti na otvorenom u ustanovama ranog i predškolskog odgoja, ali i kod postizanja boljeg razumijevanja čimbenika koji podržavaju ili ograničavaju kineziološke aktivnosti na otvorenom s djecom rane i predškolske dobi. Nadalje, ograničavajući je broj znanstvenih istraživanja koja se mogu naći o stavovima i percepciji odgojitelja, koja se konkretno odnose na primjenu kinezioloških aktivnosti na otvorenom u ustanovama ranog i predškolskog odgoja.

Ovo istraživanje je pokazalo da su nedostatak opreme (46,9\%), vremenski uvjeti $(26,6 \%) \mathrm{i} / \mathrm{ili}$ nedostatak prostora $(24,2 \%)$ najčešće prepreke za provođenje kinezioloških aktivnosti na otvorenom. Odgovor „ništa od navedenog” označen je u omjeru od $34,4 \%$, čemu razlog može biti da određeni broj ispitanika smatra da prepreka za provođenje kinezioloških aktivnosti na otvorenom nema ili da prepreke postoje, ali nisu navedene u pitanju. Nadalje, rezultati istraživanja pokazali su da najveći utjecaj na odluku odgojitelja o provođenju kinezioloških aktivnosti na otvorenom imaju oni sami, odnosno njihovi stavovi i uvjerenja (75,8\%), zatim slijede materijalni uvjeti u ustanovi $(44,5 \%)$, kurikulum ustanove $(21,9 \%)$ i u najmanjoj mjeri očekivanja od roditelja (12,5\%). Neljak (2009) navodi kako kreiranje svakog motoričkog sadržaja ovisi o njegovoj stvarnoj provedivosti, odnosno da su materijalni uvjeti rada (prostori i oprema) najčešće najveći ograničavajući čimbenik za učinkovitu realizaciju kinezioloških aktivnosti. Ipak, općenito govoreći, Petrić (2019) smatra kako uspjeh u radu s djecom u ustanovi ranog i predškolskog odgoja u najvećoj mjeri ovisi o odgojitelju i njegovoj inicijativi.

U međunarodnoj znanstvenoj studiji autora Sandseter i sur. Barriers for Outdoor Play in Early Childhood Education and Care (ECEC) Institutions: Perception of Risk in Children's Play among European Parents and ECEC (2019), provedene u okviru Erasmus+ KA2 projekta Kretanje i učenje na otvorenom, u koju je bilo uključeno pet predškolskih ustanova iz Hrvatske, Estonije, Grčke, Norveške i Portugala, istraživali su se percepcija i postupci odgojitelja i roditelja vezanih uz igru djece na otvorenome. Sve su predškolske ustanove bile smještene u urbanim područjima i imale su vanjski prostor za igru djece. U istraživanju je sudjelovalo 32 odgojitelja i 184 roditelja. Rezultati istraživanja pokazali su da vlastita uvjerenja odgojitelja i uvjeti u vrtiću imaju najveći utjecaj na donošenje odluke o puštanju djece da se igraju vani. Norveški odgojitelji vide najmanje prepreka kada se govori o provođenju aktivnosti na otvorenom, a Norveška je i zemlja u kojoj djeca provode najviše vremena igrajući se vani, dok je Grčka na zadnjem mjestu sa ukupnim vremenom od 1,5 sata boravka na otvorenom od ukupnog boravka djeteta u vrtiću.

Sat tjelesnog odgoja je jedan od organizacijskih oblika rada koji osigurava plansko i sustavno djelovanje na antropološki status djeteta (Findak, 1995). Ova je aktivnost za veliki broj djece jedina prilika za bavljenje značajnijim organiziranim 
tjelesnim vježbanjem (Petrić, 2016) jer si mnogi roditelji ne mogu materijalno priuštiti različite sportske programe koji se u dječjim vrtićima nude. Iako istraživanja idu u korist korištenja prirode i otvorenih prostora za provođenje kinezioloških aktivnosti na otvorenom, rezultati istraživanja pokazali su da se najviše ispitanika $(42,2 \%)$ ne odlučuje za provođenje kineziološke aktivnosti „sat tjelesnog odgoja” na otvorenom kroz formu: uvodni dio, glavni dio, pripremni, glavni A, glavni B i završni dio, dok ih $21,9 \%$ sat tjelesnog odgoja ne provodi na otvorenom.

Ispitanici ovog istraživanja većinom se izrazito slažu sa tvrdnjama kojima se iskazuje korisnost i dobrobit boravka na otvorenom i provođenja kinezioloških aktivnosti na otvorenom: „Smatram da djeca trebaju provoditi više vremena na otvorenom” (95,3\%); „Kad god vremenski uvjeti dozvoljavaju realizaciju kinezioloških aktivnosti treba se odlučiti za vanjski prostor” (81,3\%); „Organizacija kinezioloških aktivnosti može se realizirati na specifičnim mjestima kao što su šuma, voda, snijeg, led i sl." (68\%).

Rezultati stavova prema provedbi različitih kinezioloških aktivnosti s djecom na otvorenom pokazuju da odgojitelji pokazuju viši ili visoki stupanj slaganja za varijable: „Kada god je moguće, organizacija jutarnjeg tjelesnog vježbanja treba se provoditi na otvorenim površinama” $\mathrm{i}$, Redovito provodim pokretne igre na zraku”.

Slabiji stupanj slaganja odgojitelji su izrazili za tvrdnje: „Djeci redovito osmišljavam poticajno tjelesno vježbanje na otvorenome” i „Djecu vodim u šetnju van vrtića”.

Visoki ili viši stupanj neslaganja odgojitelji su iskazali za tvrdnju „Povremeno organiziram tjelesno vježbanje s roditeljima i djecom (zajednička druženja) na otvorenom". Prema Petrić (2019), sportska druženja sa djecom i roditeljima trebaju se provoditi u vrtiću s ciljem promocije tjelesnog vježbanja i prihvaćanja pokreta kao načina življenja. Ivaštanin i Vrbanec (2015) navode da faktor koji uveliko utječe na stvaranje partnerskih odnosa s roditeljima jest i stav odgajatelja prema roditeljskim kompetencijama i važnosti njihovog uključivanja. Nerijetko se takav negativan stav generira isključivo iz neznanja i nedovoljno razvijenih stručnih kompetencija odgajatelja, što je izvor nerazumijevanja potreba djece i roditelja, smatraju Ivaštanin i Vrbanec (2015).

Dvorski, Kokanović, Matić i Bogovčić (2015) proveli su istraživanje čiji je cilj bio ispitati stavove odgojitelja o provođenju tjelesne i zdravstvene kulture u predškolskim ustanovama i potom utvrditi postoji li razlika u stavovima o provođenju s obzirom na njihov stupanj obrazovanja. Svoje su rezultate iznijeli u radu Stavovi odgojitelja o provođenju kineziološke kulture u vrtićima s obzirom na njihov stupanj obrazovanja. Rezultati istraživanja pokazuju raskorak između profesionalnih i osobnih uvjerenja odgojitelja i djelovanja u praksi. Većina se ispitanika slaže s važnošću provođenja tjelesnih aktivnosti u dječjem vrtiću, ali ispitanici s višim stupnjem obrazovanja imaju nižu procjenu provođenja.

Autori Horvat i Morandini-Plovanić (2002) proveli su istraživanje s 33 vrtića u 11 županija Hrvatske, kojim su željeli utvrditi koliko djeca vježbaju u okviru dječjih vrtića. Pitanja su bila usmjerena na materijalne uvjete u vrtićima te na obujam vježbanja u koja su djeca uključena. Rezultati su izneseni u radu Materijalni uvjeti i opseg tjelesnog vježbanja u vrtićima. Zaključili su da je nužno uvesti promjene u 
provedbu tjelesnih aktivnosti u dječjim vrtićima koje bi smanjile negativan trend razvoja antropoloških karakteristika kod djece predškolske dobi te su ukazali na problem neprovođenja kinezioloških aktivnosti u dječjim vrtićima, gdje su rezultati istraživanja pokazali da od 33 provjerena vrtića, u 3 se nastava tjelesne i zdravstvene kulture ne izvodi.

Šumanović, Tomac i Košutić (2015) u radu Stavovi razrednih učitelja o poteškoćama u provedbi nastave tjelesne $i$ zdravstvene kulture iznose rezultate istraživanja provedenog na uzorku od 201 učitelja razredne nastave Osječko-baranjske županije. Cilj je istraživanja bio procijeniti stavove razrednih učitelja o uvjetima rada te kompetencijama učitelja kao mogućim uzrocima poteškoća u provedbi nastave tjelesne i zdravstvene kulture u nižim razredima osnovne škole i poželjne promjene u uvjetima njihova rada. Rezultati pokazuju da najveće poteškoće učiteljima stvaraju materijalni uvjeti, stoga na prvom mjestu za poboljšanje rada predlažu poboljšanje materijalnih uvjeta za rad. Također, većina učitelja smatra da je potrebno stvoriti uvjete za svakodnevnu provedbu tjelesnih aktivnosti.

Važno je naglasiti da se dobrom organizacijom, kako u zatvorenom prostoru tako i na otvorenom, mogu uspješno realizirati različite kineziološke aktivnosti. Dvorski i sur. (2015) smatraju da je nužno podizati svijest odgojitelja uključivanjem u različite oblike radionica, seminara i edukacija o utjecaju kinezioloških aktivnosti na sveukupan razvoj djeteta i važnosti redovitog provođenja, koje bi svakako pridonijele poboljšanju ovog područja, te na taj način promijenile negativan trend smanjenih fizičkih aktivnosti i razvoja pretilosti kod djece.

\section{Zaključak}

Organiziranje tjelesnog vježbanja na otvorenome u predškolskim ustanovama, neovisno o vremenskim uvjetima, pozitivno utječe na zdravlje, razvoj i učenje djece. Stoga bi odgojitelji, kao prve osobe koje provode tjelesne aktivnosti s djecom i imaju veliki utjecaj na stjecanje i promoviranje navika sustavnog tjelesnog vježbanja, trebali se odlučiti na vanjski prostor za realizaciju kinezioloških aktivnosti. Dokazano je da provođenje kinezioloških aktivnosti u prirodi značajno doprinosi pozitivnom razvoju i napretku antropoloških obilježja djece, te na taj način djeca imaju priliku povezati svoje slobodno vrijeme $s$ kretanjem i boravkom u prirodi, što je zapravo i jedna od temeljnih kompetencija koje dijete treba steći kineziološkim aktivnostima. Hoće li se i u kojoj mjeri odgojitelji odlučiti za provedbu različitih kinezioloških aktivnosti na otvorenom, ovisit će najviše o njihovim stavovima i uvjerenjima, zatim i materijalnim uvjetima u ustanovi. Nedostatak opreme, vremena i prostora najčešće su prepreke za provedbu kinezioloških aktivnosti na otvorenom. Iako se većina ispitanika uglavnom izrazito slaže s važnošću provođenja kineziološke kulture u dječjem vrtiću na otvorenom, rezultati pokazuju nižu procjenu provođenja. Kakav stav odgojitelji imaju prema tjelesnim aktivnostima reflektira njihov pogled na važnost tjelesne aktivnosti za djecu i upravo je odgovornost odgojitelja pustiti djetetu „susret” s motoričkim ili tjelesnim izazovima kroz igru i aktivnost (Iveković, 2018), kako u zatvorenom tako i na otvorenom (prirodnom) prostoru. 


\section{Literatura}

Alić, J., Petrić, V. i Badrić, M. (2016). Tjelesna i zdravstvena kultura u osnovnom školstvu: analiza propisanih nastavnih sadržaja. Napredak, 157(3), 341-359.

Dvorski, M., Kokanović, T., Matić, I. i Bogovčić, S. (2015). Stavovi odgojitelja o provođenju kineziološke kulture u vrtićima $s$ obzirom na njihov stupanj obrazovanja. U: I. Prskalo i sur. (ur.), Istraživanja paradigmi djetinjstva, odgoja $i$ obrazovanja - Kineziološka edukacija sadašnjost i budućnost. Zagreb: Učiteljski fakultet Sveučilišta u Zagrebu.

Findak, V. (1995). Metodika tjelesne i zdravstvene kulture u predškolskom odgoju. Zagreb: Školska knjiga.

Gašparović, M., Petrić, V., Štemberger, V., Rakovac, M., \& Blažević, I. (2017). Cardiorespiratory Fitness in Primary Education Pupils. Journal of Elementary Education, 10(4), 417-426.

Horvat, V. (2002). Materijalni uvjeti i opseg tjelesnog vježbanja u vrtićima [Material conditions and the extent of physical excersise in kidergartens]. U: K. Delija (ur.), Zbornik radova 11. ljetne škole kineziologa Republike Hrvatske Programiranje rada u području edukacije, sporta, sportske rekreacije i kineziterapije (90-91). Zagreb: Hrvatski kineziološki savez.

Ivanković, A. (1988). Tjelesni odgoj djece predškolske dobi. Zagreb: Školska knjiga.

Ivaštanin, I. i Vrbanec, D. (2015). Razvijanje partnerstva s roditeljima. Dijete, vrtić, obitelj, 21(79), 24-25.

Iveković, I. (2018). Stavovi odgojitelja o dječjim tjelesnim aktivnostima. Život $i$ škola, LXIV(2), 183-193.

Kalpogianni, D. E. (2019). Why are the children not outdoors? Factors supporting and hindering outdoor play in Greek public day-care centres. International Journal of Play, 8(2), 155-173.

Kinkela, D. i Marić, Ž. (2013). Neopravdano zanemareni neki organizacijski oblici rada djece predškolske dobi [Some unjustly neglected forms of work organization with preschool children]. U: V. Findak (ur.), Zbornik radova 22. ljetne škole kineziologa Republike Hrvatske: Organizacijski oblici rada u područjima edukacije, sporta, sportske rekreacije i kineziterapije (345-350). Zagreb: Hrvatski kineziološki savez.

Neljak, B. (2009). Kineziološka metodika u predškolskom odgoju. Zagreb: Kineziološki fakultet.

Novak, D., Petrić, V., Jurakić, D. \& Rakovac, M. (2014). Trends and Future Visions of Physical Education: Croatian Challenges. In M. Chin \& C. Edginton (Eds.), Physical Education and Health. Global Perspectives and Best Practice (121-133). Urbana, IL: Sagamore Publishing.

Petrić, V., Cetinić, J. i Novak, D. (2010). Razlike u funkcionalnim sposobnostima između učenika iz urbane i ruralne sredine. Hrvatski športsko medicinski vjesnik, 25(2), 117-121.

Petrić, V. (2016). Tjelesna aktivnost i zdravstvena kultura u funkciji razvoja hrvatskog društva: analiza tijeka razvoja antropoloških obilježja. U: V. Findak (ur.), 25. ljetna škola kineziologa Republike Hrvatske, zbornik radova - Kineziologija i područje edukacije, sporta, sportske rekreacije i kinezioterapije u razvitku hr- 
vatskog društva (105-111). Zagreb: Hrvatski kineziološki savez.

Petrić, V. (2019). Kineziološka metodika u ranom i predškolskom odgoju i obrazovanju. Rijeka: Učiteljski fakultet.

Prskalo, I., Findak, V. i Neljak, B. (2007). Obrazovanje budućih odgojitelja i učitelja razredne nastave za poučavanje tjelesne i zdravstvene kulture - bolonjski proces u Hrvatskoj. Kinesiology, 39(2), 171-183.

Prskalo, I., Horvat, V. i Hraski, M. (2014). Igra i kineziološka aktivnost djeteta preduvjet stvaranja navike svakodnevnog vježbanja. Croatian Journal of Education, 16(Sp.Ed.1), 57-68.

Sandseter, E. B. H., Cordovil, R., Hagen, T. L., \& Lopes, F. (2019). Barriers for Outdoor Play in Early Childhood Education and Care (ECEC) Institutions: Perception of Risk in Children's Play among European Parents and ECEC Practitioners. Child Care in Practice, 26(2) 111-129.

Sindik, J. (2009). Kineziološki programi u dječjem vrtiću kao sredstvo očuvanja djetetovog zdravlja i poticanja razvoja. Medica Jadertina, 39(1-2), 19-28.

Šumanović, M., Tomac, Z. i Košutić, M. (2015). Stavovi razrednih učitelja o poteškoćama u provedbi nastave tjelesne i zdravstvene kulture. U: I. Prskalo i sur. (ur.), Istraživanja paradigmi djetinjstva, odgoja i obrazovanja - Kineziološka edukacija sadašnjost i budućnost (76-85). Zagreb: Učiteljski fakultet Sveučilišta u Zagrebu.

World Health Organization (WHO). (2016). Obesity and overweight. Preuzeto 07.07.2020. sa https://www.who.int/news-room/fact-sheets/detail/obesityand-overweight 


\author{
Ivana Prpić \\ "Matija Gubec" Kindergarten \\ Zagreb, Croatia
}

\title{
TEACHERS' ATTITUDES TOWARD OUTDOOR KINESIOLOGICAL ACTIVITIES FOR CHILDREN AT EARLY AND PRESCHOOL AGE
}

\begin{abstract}
Kinesiological activities in early childhood and preschool education represent different types of physical exercise, and their purpose is to ensure children's motor literacy in order to enable a comprehensive and planned impact on their motor skills and optimal development of their anthropological characteristics. For most children at early and preschool age, kindergarten teachers are the first persons who organize and carry out kinesiological activities and they are responsible for physical and health education at early childhood and preschool institutions. Research has shown that outdoor physical activities significantly contribute to the positive development of children's anthropological characteristics, thus, whenever weather conditions are favourable, teachers should opt for organizing kinesiological activities outdoors. This paper examines the attitudes and views of kindergarten teachers, with the aim of achieving a better understanding of the factors that support or limit outdoor kinesiological activities for children at early and preschool age. The results of the research show that teachers' own beliefs and conditions in kindergartens have the greatest impact on the decision to do physical exercises with children outdoors. The majority of respondents generally strongly agree with the importance of organizing kinesiological activities outdoors, however, with regard to implementation the results of assessment are lower.
\end{abstract}

Key words: early and preschool education, outdoor kinesiological activities, teachers' attitudes, physical and health education 